\title{
A Comprehensive Overview on Black Scurf of Potato
}

\author{
Manoj Kumar ${ }^{1 *}$, Jaywant Kumar Singh ${ }^{1}$, Sanjeev Kumar ${ }^{2}$ and Anil Kumar ${ }^{1}$ \\ ${ }^{1}$ Department of Plant Pathology, CCS HAU, Hisar 125 004, Haryana, India \\ ${ }^{2}$ Indian Institute of Soybean research, Indore \\ *Corresponding author
}

\section{A B S T R A C T}

\begin{tabular}{|c|}
\hline Keywords \\
\hline $\begin{array}{l}\text { Culture media, } \\
\text { Mycelial, } \\
\text { Phytophthora } \\
\text { parasitica. }\end{array}$ \\
\hline Article Info \\
\hline $\begin{array}{l}\text { Accepted: } \\
\text { 29 September } 2017 \\
\text { Available Online: } \\
10 \text { October } 2017\end{array}$ \\
\hline
\end{tabular}

Keywords

Culture media, Mycelial, Phytophthora parasitica.

\section{Accepted:}

Available Online:

\section{Introduction}

Rhizoctonia solani Kuhn (teleomorph: Thanathephorus cucumeris Frank Donk) causing black scurf and stem canker on potato crop (Solanum tuberosum L.) which is economically important diseases. The Rhizoctonia disease complex is common and occurs in potato production areas throughout the world (Banville 1989; Powelson et al., 1993; Banville et al., 1996; Jeger et al., 1996; Banville and Carling 2001). The fungus limits the growth by forming cankers on sprouts, underground stems, and stolons, and makes tubers ugly by forming black scurf (sclerotia) on tuber surfaces. In few years the fungus causes significant yield reductions (upto 34\%) and can cause a significant change in size distribution of tubers (too small or large). Like other seedborne pathogens (Slack 1993; Tsror (Lahkim) et al., 1999), $R$. solani is transmitted by contaminated seed tubers, providing a mechanism for its long-distance dispersal. Once established in soil, the mycelium and sclerotia of the pathogen may then provide an additional source of primary inoculum. The recent species concept stipulates that isolates of $R$. solani possess characteristics such as some shade of brown hyphal pigmentation, branching near the distal septum of cells in young vegetative hyphae, constriction of hyphae and formation of septa a short distance from the point of 
origin of hyphal branches, dolipore septa and multinucleate cells in young vegetative hyphae (Parmeter \& Whitney, 1970).

\section{The Disease: Infection Process, Disease Development and Symptoms in Potato}

Rhizoctonia solani is a soil borne pathogen. $R$. solani colonises the below-ground potato plant surface in response to exudates release from root and shoot (Jeger et al., 1996). It proliferates on the root/stolon system to form a broad network of anastomosing hyphae. During the colonising phase the host plant remains symptomless as long as infection structures are not formed.

The early steps of infection are initiated by successive branching of runner hyphae resulting in the formation of short swollen cells giving rise to infection cushions (Hofman \& Jongebloed, 1988; Keijer, 1996). It is believed that infection cushions are prerequisite to inducing stem and stolon lesions (Keijer et al., 1997) and serve as supplementary food base for further colonisation of the plant. AG-3 forms relative small infection cushions as condensed areas in a network of interconnecting hyphae (Keijer, 1996). The infection process is both mechanical and enzymatic, the enzymes involved being DNAse, RNAse, lipase, $\alpha$ amylase, cellulose, chitinase, pectinase, pectin lyase, $\beta$-glucanase, protease and urease (Bertagnolli et al., 1996). The symptoms of the disease are found on both above and below ground parts of the plant. There are two type of symptoms caused by $R$. solani on potato are presence of black colored sclerotia on tubers (black scurf) which is most obvious sign of Rhizoctonia disease and others occurring as brown, necrotic lesions on stems and stolons below the soil surface (stem canker). Hymenia of the teleomorph may form near the soil surface on aerial stems. The hymenia do not cause damage to the plant but basidiospores enclosed in them may serve as source of subsequent infections (Banville et al., 1996). Other manifestations of infection include poor and uneven stands; premature dying; pruned stolons and sprouts; lesions on roots, stems and stolons; rosette appearance; girdled stems; necrosis in the stem-end of tubers; russeting of skin; and cracked and malformed tubers (Carling et al., 1989; Hide et al., 1992).

Infected plants generally produce either a large number of small $(<3 \mathrm{~cm}$ diameter) progeny tubers, or a few oversize tubers (Banville, 1989). Tubers can form in leaf axils of severely infected plants (Hartill, 1989). Severe stem and stolon attacks decrease fresh yield, dry matter yield and dry matter content of tubers and increase the number of deformed and small tubers, whereas the effect on haulm yield and stem number is comparatively small (Scholte, 1989). On the other hand, Gudmestad et al., 1999 report indicate that moderate infection can improve yield and increase gross income per hectare, whereas tuber and soil inoculation with $R$. solani in the greenhouse has been shown to increase the yield of marketable tuber relative to the control (Stack et al., 1999).

\section{Anastomosis groups of Rhizoctonia solani}

Rhizoctonia solani is a complex species, at least 13 related but distinct genetically anastomosis groups (AGs) (Carling et al., 2002a). AGs have been further divided into subgroups, and subgroups into subsets, on the basis of culture morphology, pathogenicity, host range, nutritional requirements and/or biochemical and genetic properties (Stevens Johnk et al., 1993; Kuninaga et al., 1997, 2000b; Nicoletti et al., 1999; Carling et al., 2002b). Binucleate Rhizoctonia isolates are associated with diseased potato plants, but cause minimal damage when tested on potatoes (Tsror, 2010). 
At present, 13 AGs (designated AG-1 through AG-13) and 21 subgroups (designated AGs 1IA, 1-IB, 1-IC, 1- ID, 2-1, 2-2-IIIB, 2-2-IV, 22-LD, 2-3, 2-4, 2-BI, 3-IIA, 3-IIB, 3-IIC, 3TB, 4-HG-I, 4-HG-II, 6- GV, 6-HG-I, 9-TX, 9-TP) are recognised (Ogoshi, 1987; Naito and Kanematsu, 1994; Carling, 1996; Hyakumachi et al., 1998; Carling et al., 1999, 2002a, b; Kuninaga et al., 2000a; Priyatmojo et al., 2001). Subgroups within AGs are partially based on differences in one or more biochemical, genetic, or pathogenic characteristic (Ogoshi, 1987).

Thirteen AGs of $R$. solani are currently known to exist (Carling et al., 2002b). Each AG can vary in host range and often geographic locations. Table lists some of the main hosts associated with individual AGs.

AG-1 and AG-2 cause only least damage to sprouts (Carling \& Leiner, 1990b). Isolates of AG-2 were collected from sclerotia on potato tubers and from hymenia and lesions on stems (Chand \& Logan, 1984).

AG-3 is the main cause of black scurf, on the tubers there is brown to black sclerotia that develop late in the growing season (Bains \& Bisht, 1995; Balali et al., 1995; Campion et al., 2003; Woodhall et al., 2008; Fiers et al., 2011). Sclerotia are most likely responsible for long distance dispersal of the pathogen (Ceresini et al., 2003). Black scurf does not physically harm tubers but reduces their market value (Banville et al., 1996). AG-3 also causes rhizoctonia stem canker (Woodhall et al., 2008). AG-3 was originally designated as a homogeneous population, causing disease only on potato. Members of this group have since been shown to infect tomato and tobacco (Kodama et al., 1982; Meyer et al., 1990; Misawa \& Kuninaga, 2010). Stevens Johnk et al., (1993) differentiated AG-3 isolates from potato and tobacco on the basis of culture appearance, fatty acid profile and pathogenicity.
Subsequently, AG-3 was divided into three subgroups: AG-3PT (potato type), AG-3TB (tobacco type) and AG-3TM (tomato type), according to the variation in nuclear ribosomal rDNA internal transcribed spacer (ITS) sequences (Kuninaga et al., 2000a; Misawa \& Kuninaga, 2010).

Isolates belonging to other AGs (AG-2, AG4, AG-5, AG-7, AG-8 and AG-9) are associated with potato diseases in different parts of the world, but cause little damage in comparison to AG-3 (Carling et al., 1987, 1998; Bains \& Bisht, 1995; Woodhall et al., 2007).

RFLP in the nuclear encoded ribosomal DNA repeat of $R$. solani revealed considerable molecular variation among and within subgroups that have been recognised previously on the basis of anastomosis, morphology and pathogenicity (Vilgalys \& Gonzalez, 1990).

Other factors like environmental may influence AG distribution. Anguiz \& Martin (1989) reported that AG-3 was more commonly associated with potato diseases at high altitudes and in cool environments, whereas AG-4 was more frequent at low altitudes and in warm climates. In contrast, Bains \& Bisht (1995) did not observe specific AGs associated with particular climatic regions, and demonstrated that AG-3, AG-4 and AG-5 occurred on infected potato plants grown in a single potato field. Alternative hosts for $R$. solani may also affect the distribution of the fungus, with solanaceous weeds acting as possible reservoirs for the pathogen (Tsror, 2010).

AG-1 and AG-2 cause least damage to sprouts (Carling \& Leiner, 1990a). Isolates of AG-2 were collected from sclerotia on potato tubers and from hymenia and lesions on stems (Chand \& Logan, 1984). 
AG-3 is by far the most aggressive AG on potato, and indiscriminately attacks roots, stolons and subterranean portions of the main stem (Carling \& Leiner, 1990a; Bains \& Bisht, 1995). Although AG-3 is virulent across a broad range of temperatures (5 to 25 ${ }^{\circ} \mathrm{C}$ ), it is particularly aggressive at 10 to 15 ${ }^{\circ} \mathrm{C}$, where other AGs generally become less damaging (Carling \& Leiner, 1990a). On average, isolates from hymenia were significantly more virulent than isolates from lesions, but neither differed significantly in virulence from isolates obtained from sclerotia or soil (Carling \& Leiner, 1990b; Hill \& Anderson, 1989).

\section{Hosts range of $\boldsymbol{R}$. solani}

It is believed that Rhizoctonia species other than $R$. solani have no or little role in causing disease on potato (Carling and Leiner, 1990b). Sturz et al., (1995) survey on Prince Edward Island 80 species and found 56 that harboured $R$. solani. Further inoculation trials with 61 weed species showed that 28 could be infected by the anastomosis groups AG3 and AG5. AG5 has been isolated from winter wheat (Woodhall et al., 2012) and couch grass in the UK (Woodhall and Lees, 2004). $R$. solani AG-3 has also been isolated from the roots and stems of many weeds present in Spanish potato fields (Chenopodium album, Diplotaxis eurocoides, Solanum nigrum, and Sorghum halepense) (El Bakali et al., 2000). Bains et al., (2002) found that neither Beta vulgaris, Brassica campestris, Hordeum vulgare, Pisum sativum, Triticum aestivum nor Zea mays were able to be infected by Rhizoctonia. However, other studies have isolated $R$. solani AG-3 from barley (Murray 1981) and sugar beet (Windels and Nabben 1989).

\section{Eco-friendly management of black scurf}

Since black scurf is soil and tuber borne disease. So for effective management of this disease, it is requires implementation of an integrated disease management approach and knowledge of each of its stages. Inoculum source and its impact on progeny tubers play an important part in strategies for controlling R. solani on potato. R. solani is a tuber- and soilborne pathogen (Frank and Leach 1980; Powelson et al., 1993). The ability to detect the presence of the pathogen in the crop or the soil, to determine threshold levels of inoculums and to investigate the relative importance of seed and soil borne inoculum provides information on which disease management decisions can be based (Lees et al., 2002; Brierley et al., 2009). Although the most important measures are cultural, chemical controls can be utilized in some cases (Harrison et al., 1970; Powelson et al., 1993; Wicks et al., 1995; Johnston 1995; Loria et al., 1997).

\section{Cultural Control}

The value of cropping practices to control soil borne diseases has been recognized long before fungicides and fumigants were commonly available. Agronomic factors such as plant material, cultivar, crop rotation, soil management, tillage, irrigation, pesticide application, haulm destruction, harvesting, crop residues, volunteer plants and storage all have a profound influence on the incidence and severity of potato rhizoctoniasis (Jeger et al., 1996).

\section{Disease free tubers of potato}

Since infected seed tubers form the main source of inoculum, black scurf disease can be managed to a large extent through the use of certified seed free of sclerotia. Planting clean seed tubers or tubers treated with antagonists or fungicides can be helpful in few conditions. Therefore, keep an eye on black scurf incidence on seed tubers can be the first stage in preventing the disease. A common recommendation is to plant disease- 
free tubers, although this is not always possible. In addition, each country defines regulations differently.

\section{Crop rotation}

Monoculture should be avoided, because of it is well recognized for further inoculums source for soil borne diseases. Rotations of 35 years are often necessary to effectively reduce losses caused by $R$. solani. The frequency with which potatoes are cultivated has a greater effect on black scurf incidence than crop rotation as such. An increased number of potato cropping cycles enhanced the incidence and severity of stem canker due to the increase in soilborne inoculums density (Scholte 1992; Honeycutt et al., 1996). Ideally, three-year rotations or longer are often required to reduce damage caused by $R$. solani (Banville et al., 1996). Despite the fact that crop rotation is practiced to manage Rhizoctonia diseases, an increase in the disease has been observed in potato fields (Celetti et al., 1990; Errampalli et al., 1999).
In different 3-year cropping systems (soybean-canola, soybean-barley, sweet corncanola, sweet corn-soybean, green bean-sweet corn, canolasweet corn, barley-clover) followed by potato, compared with continuous potato growing, both rotation and cropping sequence were important in the microbial characteristics, soilborne disease and tuber quality (Larkin and Honeycutt 2006). Rhizoctonia disease incidence and severity were reduced in most rotations, compared with the continuous potato, where canola, barley or sweet corn prior to potato had the lowest levels of Rhizoctonia disease and the best tuber quality (Larkin and Honeycutt 2006). Rhizoctonia disease was aggravated by rotation with certain legumes, sugar beet and broccoli (Baker and Martinson 1970). Results from different crop-rotation programs vary greatly with respect to their effect on Rhizoctonia incidence (Carter et al., 2003; Peters et al., 2003). Economical rotation systems should be developed according to particular growing conditions.

Table.1 Anastomosis groups of Rhizoctonia solani, host, associated valid names and persons credited with discovery of the AG (adapted from Roberts, 1999)

\begin{tabular}{|c|c|c|c|}
\hline $\mathbf{A G}$ & Typical hosts & Discovery credited to: & $\dagger$ \\
\hline 1 & Rice, corn, bean & Parmeter et al., (1969)* & $\begin{array}{l}\text { T. sasakii (AG1-IA) } \\
\text { T. microsclerotia (AG1-IB) }\end{array}$ \\
\hline 2 & Crucifers, sugar beet, carrot & Parmeter et al., (1969)* & \\
\hline 3 & Potato, tobacco & Parmeter et al., (1969)* & \\
\hline 4 & Bean, cereals, root rots & Parmeter et al., (1969)* & T. praticola \\
\hline 5 & Potato, turf grass, root rots & Ogoshi, (1987) & \\
\hline 6 & Orchid mycorrhizal & Kuninaga et al., (1978) & \\
\hline 7 & $\begin{array}{l}\text { Carnation, radish, soybean, } \\
\text { saprophyte }\end{array}$ & Homma et al., (1983) & \\
\hline 8 & Cereals & Natio et al., (1985) & \\
\hline 9 & $\begin{array}{l}\text { Crucifers, potatoes, } \\
\text { saprophyte }\end{array}$ & Carling et al., (1987) & \\
\hline 10 & Wheat, barley & Ogoshi et al., (1990) & \\
\hline 11 & Lupin, wheat & Carling et al., (1996) & \\
\hline 12 & Orchid mycorrhizal & Carling et al., (1999) & \\
\hline 13 & Cotton & Carling et al., (1990b) & \\
\hline
\end{tabular}

*Presence of four anastomosis groups before Parmeter et al., (1969), who is credited with designation of AG1 to AG4.

$\dagger$ In some classifications, individual AGs have been classed as species and given specific names but this has not generally been accepted. 


\section{Soil moisture and the management}

Practices that favour rapid emergence like shallow planting or using greened seed tubers seem to restrict stem canker infection (Carling \& Leiner, 1990b; Jeger et al., 1996) owing to the greater resistance to infection of mature than immature tissue such as emerging spouts and stolons. Firman \& Allen (1995) showed that an increase in plant density resulted in an increased severity of black scurf on progeny tubers. Irrigation has variable effects on soil borne diseases. The timing and frequency of irrigation in relation to tuber initiation and tuber disease onset appears to be one of the factors determining tuber disease development of potato tuber diseases. It was reported that lower temperatures and increased soil moisture are favorable for stem canker infection (Hide and Firmager, 1989). Excessive soil moisture may affect potato tubers and lead to swollen lenticels and increased susceptibility to tuber borne infections (Adams and Stevenson, 1990). Moderate soil moisture was also to be conducive for black dot infection and disease development (Read and Hide, 1988).

At light irrigation and heavy irrigation (at 1520 day), the $\%$ disease incidence was $16.7 \%$ and $36.3 \%$ whereas disease intensity was 2.8 and 3.7 respectively. The soil pulverization during summer (April-June) at 20 days intervals was found very effective to minimizing the $R$. solani population up to 1x102 propagules/g soil (Singh et al., 2005).

High levels of nitrogen and phosphorus in soil enhance sclerotium formation and disease severity, probably due to more nutritious tuber exudates (Allington, 1936; Papavizas \& Davey, 1961; Scholte, 1992). It therefore stands to reason that disease can be reduced by fertilization, although the survival of $R$. solani in artificially infested soil was shown to be little affected by soil fertility.
Compost-amended soil has been found to be suppressive against nematodes, bacteria and soilborne fungi in various cropping systems (Hoitink \& Fahy, 1986), although an increase of disease due to compost application has also been demonstrated (Nelson et al., 1983; Tuitert et al., 1998).

The variation in suppressiveness to $R$. solani was ascribed to compost maturity, with immature compost generally being condusive (Nelson et al., 1983; Tuitert et al., 1998). Antagonist enrichment of composts increases the reliability of disease suppressiveness of the composts towards $R$. solani (Postma et al., 2003). Organic amendment viz. Vermicompost, Neem Cake and FYM (Farm Yard Manure) showed the inhibition effect on the growth of $R$. solani (Rahul et al., 2014).

\section{Harvesting time and dehaulming}

Harvesting methods that are used in potato production can affect the level of black scurf (Dijst et al., 1986). Dijst (1985) suggested that early haulm killing promotes development of sclerotia. Advancing the killing of vines does not lead to a rapid disintegration of the roots. The initially fully functional root system continues to function as water pump for about a week (Dijst, 1985). As evaporation through the foliage ceases, tubers serve as a sink for the water surplus, consequently increasing in mass and commencing leakage. However, the use of herbicides and other chemicals to kill potato shoots just before harvest time can also lead to increased incidence and severity of black scurf on potato tubers (Mulder et al., 1992). Green-crop-harvesting (harvesting the immature crop mechanically and returning the tubers to the soil for curing before final harvesting two to four weeks later) and immature-crop-harvesting (pulling haulms and collecting the tubers by hand) often result in low levels of black scurf (Mulder et al., 
1992; Lootsma \& Scholte, 1996). Green-crop harvesting has the additional advantage of allowing the application of chemicals or antagonists with the first lifting of the tubers, resulting in increased control of black scurf (Mulder et al., 1992).

\section{Biological control}

Biological management of pathogenic organisms is considered to be a potential tool. A variety of bioagents have been used to control the pathogen, R.solani, and Trichoderma species is the most exploited one (Beagle et al., 1985). Both Trichoderma harzianum and Trichoderma viride significantly suppress the mycelial growth of R. solani isolates (Hussain et al., 2014). However, Trichoderma harzianum is more effective as compared to T.viride. Trichoderma harzianum produces protease enzyme that is capable of degrading the pathogen cell and reduce the capacity pathogen to grow or infect the plant (Elad et.al., 1980). Suppression of R. solani has been achieved with various fungi and bacteria (actinomycetes, Bacillus, fluorescent Pseudomonas), as well as nematodes (Escande and Echandi 1991; Tuitert et al., 1998). Arora (2008) reported the treatment of Trichoderma viride after seed dressing with boric acid (1.5\%) significantly minimized the black scurf disease on potato tubers.

A hypovirulent $\mathrm{R}$. solani isolate significantly reduced (by 56\%) the area of infected potato stem tissue under controlled conditions by inoculation with both virulent and hypovirulent isolates (Bandy and Tavantzis 1990). Plants inoculated with the hypovirulent isolate had a significantly higher stolon and stem dry weight (4-fold and 1.7-fold increase, respectively). However, the same hypovirulent isolate failed to reduce disease severity or to stimulate plant growth when was applied to naturally contaminated seed tubers (Bandy and Tavantzis 1990).

\section{Chemical control}

A number of fungicides have been evaluated as seed or soil treatment against black scurf and stem canker, e.g. azoxystrobin, benomyl, carbendazim, fluazinam, fludioxonil, imazalil, iprodione, mepronil, pencycuron, propiconazole, quintozene (PCNB), thiabendazole, thiram and tolclofos-methyl (Davis et al., 1971; Chand \& Logan, 1982; Leach \& Murdoch, 1985; Sumner, 1987; Jager et al., 1991; Olaya et al., 1994; Wicks et al., 1995; Virgen-Calleros et al., 2000), but mostly provided varying and inconsistent control. $R$. solani has acquired resistance to both protectant organic fungicides such as captan, dichlone, maneb, quintozene, thiram and tolclofos-methyl (Shatla \& Sinclair, 1963; Elsaid \& Sinclair, 1964; Meyer \& Parmeter, 1968; Van Bruggen \& Arneson, 1984) and to systemic fungicides such as benomyl, carboxin, dichlozoline, oxycarboxin, thiophanate-methyl and 2-(thiocyanomathylthio)-benzothiazole (TCMTB) (Martin et al., 1984). In most cases the resistance was temporary and possibly due to enzymatic adaptation (Elsaid \& Sinclair, 1964). For quintozene and TCMTB, however, the resistance remained stable (Shatla \& Sinclair, 1963) and ensued as a consequence of genetic changes. Control of $R$. solani in infested field soil with methyl bromide fumigation is highly effective but tends to aggravate disease derived from infected tubers. Alternatives to methyl bromide, such as methyl iodide, metam-sodium, dichloropropene, chloropicrin, 1,2-dibromo-3-chloropropane and dazomet have been evaluated and found to be equally effective (Ohr et al., 1996; Csinos et al., 1997). Boric acid and pencycuron are the two chemicals that are frequently used by Indian farmers to control black scurf (Khurana et al., 2001). Application of boric acid to seed tubers is 
recommended before sprouting usually prior to cold storage (Singh et al., 2002; Arora et al., 2006) whereas pencycuron can be applied to the sprouted tubers at planting (Thind et $a l ., 2002)$. Bioefficacy of different fungicides [penflufen 240 FS $(0.042 \%)$, penflufen 240 FS $(0.062 \%)$, penflufen 240 FS $(0.083 \%)$, Monceren 250 EC (0.25\%), carbendazim 50 WP $(0.3 \%)$ and Emisan 6 FS (0.25\%)] was evaluated against black scurf of potato by dip treatment on Kufri Bahar cultivar. Penflufen $(0.062,0.083 \%)$ dip treatment of scurf infected tubers for 10 minutes provided more than $97 \%$ disease control (Anil Kumar and Kushal Raj, 2016).

Black scurf of Potato is very complex disease to manage. Black scurf is caused by Rhizoctonia solani which is soil and tuber borne disease. Multiple inoculum sources such as soil, tubers, crop residues, raw organic manure, alternative hosts), the genetic and pathogenic variability of the pathogen, the long crop cycle including multiple stages in the tuber handling chain, from seed to the shelf, and limited practical control measures where limited use of chemical is a main goal in the trading markets, all contribute to the difficulty to adequately control the disease in a market with a very low tolerance for visible blemish on harvested tubers. Monitoring disease levels in seed tuber lots enables selection of suitable lots for seed production, thus avoiding the disease as a major proven approach applied that has been used to control other seedborne and soilborne pathogens. In addition, using advanced molecular techniques for the detection of $\mathrm{R}$. solani inoculum in the soil will allow researchers to develop a decision support system to support growers in the selection of seed lots and fields to be cropped with potato. The additional information about epidemiology of the disease is an essential part of integrated disease management. The sustainable management of such a disease apparently requires integrated solutions, combining cultural control practices which reduce inoculum levels in the soil and tuber exposure to soil infestation. To manage Rhizoctonia diseases consequently remains a challenge, despite the current useful knowledge gathered on the biology and epidemiology of the pathogen.

\section{References}

Adams, S.S. and Stevenson, W.R. 1990. Water management, disease development and potato production. Am. Potato J., 67: 3-11.

Allington, W.B. 1936. Sclerotial formation in Rhizoctonia solani as affected by nutrition and other factors. Phytopathology, 26: 831844.

Anguiz, R. and Martin, C. 1989. Anastomosis groups, pathogenicity, and other characteristics of Rhizoctonia solani isolated from potatoes in Peru. Plant Disease, 73: 199-201.

Arora, R. K. 2008. Management of black scurf of potato with the integrated use of Trichoderma viride and boric acid. Potato journal, 35(3-4): 130-133.

Arora, R.K., Sharma, J., Garg, I.D., Singh, R.K. and Somani, A. K. 2006. Boric Acid for Control of Tuber Borne Diseases. Central Potato Research Institute, Shimla, India. Technical Bulletin, 35: 1-4.

Bains, P.S. and Bisht, V.S. 1995. Anastomosis group identity and virulence of Rhizoctonia solani isolates collected from potato plants in Alberta, Canada. Plant Disease, 79: 241242.

Bains, P.S., Bennypaul, H.S., Lynch, D.R., Kawchuk, L.M. and Schaupmeyer, C.A. 2002. Rhizoctonia disease of potatoes (Rhizoctonia solani): fungicidal efficacy and cultivar susceptibility. American Journal of Potato Research, 79: 99-106.

Baker, R. and Martinson, C.A. 1970. Epidemiology of diseases caused by Rhizoctonia solani. In: J.R. Parmeter (ed.). Rhizoctonia solani: Biology and pathology. University of California Press, Berkeley. pp 172-188

Balali GR, Neate SM, Scott ES, Whisson DL, and 
Wicks TJ, 1995. Anastomosis group and pathogenicity of isolates of Rhizoctonia solani from potato crops in South Australia. Plant Pathology, 44: 1050-1057.

Bandy, B.P. \& Tavantzis, S.M. 1990. Effect of hypovirulent Rhizoctonia solani on Rhizoctonia disease, growth, and development of potato plants. American Potato Journal, 67: 189-199.

Banville, G.B. and Carling, D.E. 2001. Rhizoctonia canker and black scurf. In: Stevenson WR, Loria R, Franc G, Weingartner DP. (eds) Compendium of Potato Diseases. St Paul, MN, APS Press, pp. 36-37.

Banville, G.J. 1989. Yield losses and damage to potato plants caused by Rhizoctonia solani Kühn. American Potato Journal, 66: 821834.

Banville, G.J., Carling, D.E. and Otrysko, B.E. 1996. Rhizoctonia disease on potato. In: Sneh B, Jabaji-Hare S, Neate S, Dijst G, eds. Rhizoctonia Species. Taxonomy, Molecular Biology, Ecology, Pathology and Disease Control. Dordrecht, The Netherlands: Kluwer Academic, pp. 321330.

Beagle-Ristaino, J.E. and Papavizas, G.C. 1985. Biological controls of Rhizoctonia stem canker and black scurf of potato. Phytopathology, 75: 560-564.

Bertagnolli, B.L., Dal Soglio, F.K. and Sinclair, J.B. 1996. Extracellular enzyme profiles of the fungal pathogen Rhizoctonia solani isolate 2B-12 and two antagonists, Bacillus megaterium strain B153-2-2 and Trichoderma harzianum isolate Th008. I. Possible correlations with inhibition of growth and biocontrol. Physiological and Molecular Plant Pathology, 48: 145-160.

Brierley, J.L., Stewart, J.A. and Lees, A.K. 2009. Quantifying potato pathogen DNA in soil. App Soil Ecol., 41: 234-238.

Campion, C., Chatot, C., Perraton, B. and Andrivon, D. 2003. Anastomosis groups, pathogenicity and sensitivity to fungicides of Rhizoctonia solani isolates collected on potato crops in France. European Journal of Plant Pathology, 109: 983-992.

Carling, D.E. 1996. Grouping in Rhizoctonia solani by hyphal anastomosis reaction. In:
B. Sneh, S. Jabaji-Hare, S. Neate \& G. Dijst (eds). Rhizoctonia species: Taxonomy, molecular biology, ecology, pathology and disease control. Kluwer Academic, Dordrecht, pp. 35-47

Carling, D.E. and Leiner, R.H. 1990a. Effect of temperature on virulence of Rhizoctonia solani and other Rhizoctonia on potato. Phytopathology, 80: 930-934.

Carling, D.E. and Leiner, R.H. 1990b. Virulence of isolates of Rhizoctonia solani AG-3 collected from potato plant organs and soil. Plant Disease, 74: 901-903.

Carling, D.E., Baird, R.E., Gitaitis, R.D., Brainard, K.A. and Kuninaga, S. 2002a. Characterization of AG-13, a newly reported anastomosis group of Rhizoctonia solani. Phytopathology, 92: 893-899.

Carling, D.E., Brainard, K.A., Virgen-Calleros, G. and Olalde-Portugal, V. 1998. First report of Rhizoctonia solani AG-7 on potato in Mexico. Plant Disease, 82: 127.

Carling, D.E., Kuninga, S. and Brainard, K.A. 2002b. Hyphal anastomosis reactions, rDNA-ITS sequences and virulence levels among subsets of Rhizoctonia solani anastomosis group-2 (AG-2) and AG-BI. Phytopathology, 92: 43-50.

Carling, D.E., Leiner, R.H. and Kebler, K.M. 1987. Characterisation of a new anastomosis group (AG-9) of Rhizoctonia solani. Phytopathology, 77: 1609-1612.

Carling, D.E., Leiner, R.H. and Westphale, P.C. 1989. Symptoms, signs and yield reduction associated with Rhizoctonia disease of potato induced by tuber-borne inoculum of Rhizoctonia solani AG-3. American Potato Journal, 66: 693-701.

Carling, D.E., Pope, E.J., Brainard, K.A. and Carter, D.A. 1999. Characterization of mycorrhizal isolates of Rhizoctonia solani from an orchid, including AG-12, a new anastomosis group. Phytopathology, 89: 942-946.

Carter, M.R., Kunelius, H.T., Sanderson, J.B., Kimpinski, J., Platt, H.W. and Bolinder, M.A. 2003. Productivity parameters and soil health dynamics under longterm 2-year potato rotations in Atlantic Canada. Soil and Tillage Research, 72: 153-168.

Celetti, M.J., Johnston, H.W., Kimpinski, J., Platt, 
H.W. and Martin, R.A. 1990. Incidence of soil-borne plant pathogens isolated from barley and winter wheat, and other crops in the rotation on Prince Edward Island. Plant Pathol., 39: 606-611.

Ceresini, P.C., Shew, H.D., Vilgalys, R.J., Gale, L.R. and Cubeta, M.A. 2003. Detecting migrants in populations of Rhizoctonia solani anastomosis group 3 from potato in North Carolina using multilocus genotype probabilities. Phytopathology, 93: 610-615.

Chand, T. and Logan, C. 1982. Fungicidal control of stem canker and black scurf of potato. Annals of Applied Biology, 100: 52-53.

Chand, T. and Logan, C. 1984. Antagonists and parasites of Rhizoctonia solani and their efficacy in reducing stem canker of potato under controlled conditions. Transactions of the British Mycological Society, 83: 107112.

Csinos, A.S., Johnson, W.C., Johnson, A.W., Summer, D.R., Mcpherson, R.M. and Gitaitis, R.D. 1997. Alternative fumigants for methyl bromide in tobacco and pepper transplant production. Crop Protection, 16: 585-594.

Davis, J.R., Groskopp, M.D. and Callihan, R.H. 1971. Seed and soil treatments for control of Rhizoctonia on stems and stolons of potato. Plant Disease Reporter 55: 550554.

Dijst, G. 1985. Investigations on the effect of haulm destruction and additional root cutting on black scurf on potato tubers. Netherlands Journal of Plant Pathology, 91: 153-162

Dijst, G., Bouman, A., Mulder, A. and Roosjen, J. 1986. Effect of haulm destruction supplemented by cutting off roots on the incidence of black scurf and skin damage, flexibility of harvest period and yield of seed potatoes in field experiments. Netherlands Journal of Plant Pathology, 92: 287-303.

El Bakali, M. A., Martin, M. P., Garcia F. F., Moret, B. A., and Nadal P.M., 2000. "First report of Rhizoctonia solani AG-3 on Potato in Catalonia (NE Spain)." Plant Disease, 84: 806.

Elad, Y., Chet, I. and Katan, J. 1980. Trichoderma harzianum, a biocontrol agent effective against Sclerotium rolfsii and Rhizoctonia solani. Phytopathology, 70(2): 119-121.

Elsaid, H.M. and Sinclair, J.B. 1964. Adapted tolerance to organic fungicides by isolates of Rhizoctonia solani from seedling cotton. Phytopathology, 54: 518-522.

Errampalli, D., Arsenault, W. and MacIsaac, K.A. 1999. Efficacy of seed piece treatment fungicide, maxim (fludioxonil), dividend / maxim (difenaconazole / fludioxonil) and easout (thiophanate-methyl) on black scurf, silver scurf and dry rot of potatoes, 19981999. Agri- Food Can Pest Manag Res Rep., 113: 305-307.

Escande, A.R. and Echandi, E. 1991. Protection of potato from Rhizoctonia canker with binucleate Rhizoctonia fungi. Plant Pathol., 40:197-202.

Fiers, M., Edel-Hermann, V. and Héraud, C. 2011. Genetic diversity of Rhizoctonia solani associated with potato tubers in France. Mycologia, 103: 1230-1244.

Firman, D.M. and Allen, E.J. 1995. Effects of seed, planting density and planting pattern on the severity of silver scurf (Helminthosporium solani) and black scurf (Rhizoctonia solani) diseases of potatoes. Annals of Applied Biology, 127: 73-85.

Frank, J.A. and Leach, S.S. 1980. Comparison of tuber-borne and soil-borne inoculum in the Rhizoctonia disease of potato. Phytopathology, 70: 51-53.

Gudmestad, N.C., Secor, G.A. and Salas, B. 1999. Economic effects of seed-borne Rhizoctonia of potato. Abstracts of the 14th Triennial Conference of the European Association for Potato Research, Sorrento, 2-7 May 1999, pp. 672-673.

Harrison, M.D., Johnson, G., Barmington, R.D. 1970. Comparison of two methods of PCNB application for control of Rhizoctonia infection of potatoes. $\mathrm{Am}$ Potato J., 47: 386-393.

Hartill, W.F.T. 1989. Some effects of Rhizoctonia solani on growth and yield of potatoes. Potato Research, 32: 283-292.

Hide, G. A. and Frienger, J.P. 1989. Effects of soil temperature and moisture on stem canker (Rhizoctonia solani) disease of potatoes. Potato Res., 32: 75-86.

Hide, G.A., Read, P.J. and Hall, S.M. 1992. Stem 
canker (Rhizoctonia solani) on three early and three maincrop potato cultivars: Effects of seed tuber size on growth and yield. Annals of Applied Biology, 120: 391-403.

Hill, C.B. and Anderson, N.A. 1989. An evaluation of potato disease caused by isolates of Rhizoctonia solani AG-3. American Potato Journal, 66: 709-721.

Hofman, T.W. and Jongebloed, P.H.J. 1988. Infection process of Rhizoctonia solani on Solanum tuberosum and effects of granular nematicides. Netherlands Journal of Plant Pathology, 94: 243-252.

Hoitink, H.A.J. and Fahy, P.C. 1986. Basis for the control of soilborne plant pathogens with composts. Annual Review of Phytopathology, 24: 93-114.

Honeycutt, C.W., Clapham, W.M. and Leach, S.S. 1996. Crop rotation and $\mathrm{N}$ fertilization effects on growth, yield, and disease incidence in potato. American Potato Journal, 73: 45-61.

Hussain, A., Awan, M.S., Khan, S.W., Anees, M., Ali, S., Abbas, Q. and Ali, A. 2014. Bioefficacy of botanical extracts and bioagents against sclerotial isolates of Rhizoctonia solani. J. Bio. Envir. Sci., 4: 370-380.

Hyakumachi, M., Mushika, T., Ogiso, Y., Toda, T., Kageyama, K. and Tsuge, T. 1998. Characterization of a new cultural type (LP) of Rhizoctonia solani AG2-2 isolated from warm-season turfgrasses, and its genetic differentiation from other cultural types. Plant Pathology, 47: 1-9.

Jager, G., Velvis, H., Lamers, J.G., Mulder, A. and Roosjen, J. 1991. Control of Rhizoctonia solani in potato by biological, chemical and integrated measures. Potato Research, 34: 269-284.

Jeger, M.J., Hide, G.A., Van Den Boogert, P.H.J.F., Termorshuizen, A.J. and Van Baarlen, P. 1996. Pathology and control of soil-borne fungal pathogens of potato. Potato Research, 39: 437-469.

Johnston, H.W. 1995. Efficacy of potato seed piece fungicide treatments for control of tuber diseases. Agri-Food Can Pest Manag Res Rep., 130: 84-86.

Keijer, J. 1996. The initial steps of the infection process in Rhizoctonia solani. In: B. Sneh,
S. Jabaji-Hare, S. Neate \& G. Dijst (eds). Rhizoctonia species: Taxonomy, molecular biology, ecology, pathology and disease control. Kluwer Academic, Dordrecht. pp. 149-162

Keijer, J., Korsman, M.G., Dullemans, A.M., Houterman, P.M., De Bree, J. and Van Silfhout, C.H. 1997. In vitro analysis of host plant specificity in Rhizoctonia solani. Plant Pathology, 46: 659-669.

Khurana, S.M.P., Thind, T.S, and Mohan, C. 2001. Diseases of potato and their management In, Diseases of fruits and vegetables and their management. Thind TS (ed.) Kalyani Publishers, New Delhi. Pp. 237-265.

Kodama, T., Horimoto, K. and Ogoshi, A. 1982. On the brown spot of eggplant caused by Thanatephorus cucumeris (Frank) Donk (Rhizoctonia solani) AG3. Annals of the Phytopathological Society of Japan, 48: 356.

Kumar, A. and Raj, K. 2016. Evaluation of different fungicides against black scurf of potato caused by Rhizoctonia solani. Indian Journal of Plant Protection, 44(1):110-115.

Kuninaga, S., Carling, D.E., Takeuchi, T. and Yokosawa, R. 2000b. Comparison of rDNA-ITS sequences between potato and tobacco strains in Rhizoctonia solani AG-3. Journal of General Plant Pathology, 66: 211.

Kuninaga, S., Natsuaki, T., Takeuchi, T. and Yokosawa, R. 1997. Sequence variation of the rDNA ITS regions within and between anastomosis groups in Rhizoctonia solani. Current Genetics, 32: 237-43.

Kuninaga, S., Nicoletti, R., Lahoz, E. and Naito, S. 2000a. Ascription of Nt-isolates of Rhizoctonia solani to anastomosis group 21 (AG-2-1) on account of rDNA-ITS sequence similarity. Journal of Plant Pathology, 82: 61-4.

Kuninaga, S., Yokosawa, R. and Ogoshi, A. 1978. Anastomosis grouping of Rhizoctonia solani Kühn isolated from non-cultivated soils. Annals of the Phytopathological Society of Japan, 44: 591-598.

Larkin, R.P. and Honeycutt, C.W. 2006. Effects of different 3-year cropping systems on soil microbial communities and Rhizoctonia 
diseases of potato. Phytopathology, 96: 6879.

Leach, S.S. and Murdoch, C.W. 1985. Evaluation of thiabendazole and pentachloronitrobendazole for control of the Rhizoctonia disease complex on white potato (Solanum tuberosum L.). American Potato Journal, 62: 459-469.

Lees, A.K., Cullen, D.W., Sullivan, L. and Nicolson, M.J. 2002. Development of conventional and quantitative real-time PCR assays for the detection and identification of Rhizoctonia solani AG-3 in potato and soil. Plant Pathol., 51: 293-302.

Lootsma, M. and Scholte, K. 1996. Effects of soil disinfection and potato harvesting methods on stem infection by Rhizoctonia solani Kühn in the following year. Potato Research, 39: 15-22.

Loria, R., Bukhalid, R.A., Fry, B.A. and King, R.R. 1997. Plant pathogenicity in the genus Streptomyces. Plant Disease, 81: 836-846.

Martin, S.B., Lucas, L.T. and Campbell, C.L. 1984. Comparative sensitivity of Rhizoctonia solani and Rhizoctonia-like fungi to selected fungicides in vitro. Phytopathology, 74: 778-781.

Meyer, J.C., Van Wyk, R.J. and Phillips, A.J.L. 1990. Rhizoctonia leaf spot of tobacco in South Africa. Plant Pathology, 39: 206207.

Meyer, R.W. and Parmeter, J.R. 1968. Changes in chemical tolerance associated with heterokaryosis in Thanatephorus cucumeris. Phytopathology, 58: 472-475.

Misawa, T. and Kuninaga, S. 2010. The first report of tomato foot rot caused by Rhizoctonia solani AG-3 PT and AG-2-Nt and its host range and molecular characterization. Journal of General Plant Pathology, 76: 310-319.

Mulder, A., Turkensteen, L.J. and Bouman, A. 1992. Perspectives of green-cropharvesting to control soil-borne and storage diseases of seed potatoes. Netherlands Journal of Plant Pathology, 98 (2): 103-114.

Murray, D.I.L. 1981. Rhizoctonia solani causing barley stunt disorder. Trans Br Mycol Soc., 76: 383-395.

Naito, S. and Kanematsu, S. 1994. Characterization and pathogenicity of a new anastomosis subgroup AG-2-3 of Rhizoctonia solani Kühn isolated from leaves of soybean. Annals of the Phytopathological Society of Japan, 60: 681-690.

Nelson, E.B., Kuter, G.A. and Hoitink, H.A.J. 1983. Effects of fungal antagonists and compost age on suppression of Rhizoctonia damping-off in container media amended with composted hardwood bark. Phytopathology, 73: 1457-1462.

Nicoletti, R., Lahoz, E., Kanematsu, S., Naito, S. and Contillo, R. 1999. Characterization of Rhizoctonia solaniisolates from tobacco fields related to anastomosis groups 2-1 and BI (AG 2-1 and AG BI). Journal of Phytopathology, 147: 71-77.

Ogoshi, A. 1987. Ecology and pathogenicity of anastomosis and intraspecific groups of Rhizoctonia solani Kühn. Annual Review of Phytopathology, 25: 125-143.

Ohr, H.D., Sims, J.J., Grech, N.M., Becker, J.O. and Mcgiffen, M.E. J. 1996. Methyl iodide, an ozone-safe alternative to methyl bromide as a soil fumigant. Plant Disease, 80: 731735.

Olaya, G., Abawi, G.S. and Barnard, J. 1994. Response of Rhizoctonia solani and binucleate Rhizoctonia to five fungicides and control of pocket rot of table beets with foliar sprays. Plant Disease, 78: 1033-1037.

Papavizas, G.C. and Davey, C.B. 1961. Saprophytic behavior of Rhizoctonia in soil. Phytopathology 51: 693-699. Parmeter JR, Sherwood RT and Platt WD, 1969. Anastomosis grouping among isolates of Thanatephorus cucumeris. Phytopathology, 59: 1270-1278.

Parmeter, J.R. and Whitney, H.S. 1970. Taxonomy and nomenclature of the imperfect state. In: J.R. Parmeter (ed.). Rhizoctonia solani: Biology and pathology. University of California Press, Berkeley. Pp. 7-19

Peters, R.D., Sturz, A.V., Carter, M.R. and Sanderson, J.B. 2003. Developing diseasesuppressive soils through crop rotation and tillage management practices. Soil and Tillage Research, 72: 181-192.

Postma, J., Montanari, M. and Van Den Boogert, P.H.J.F. 2003. Microbial enrichment to 
enhance the disease suppressive activity of compost. European Journal of Soil Biology, 39: 157-163.

Powelson, M.L., Johnson, K.B. and Rowe, R.C. 1993 Management of diseases caused by soilborne pathogens. In: Rowe RC. (ed) Potato Health Management. St Paul, MN, APS Press, pp. 149-156.

Priyatmojo, A., Escapalao, V.E., Tangonon, N.G., Pascual, C.B., Suga, H., Kageyama, K. and Hyakumachi, M. 2001. Characterization of a new subgroup of Rhizoctonia solani anastomosis group 1 (AG-1-ID), causal agent of a necrotic leaf spot on coffee. Phytopathology, 91: 1054-1061.

Rahul,S. N., Singh, V. P., Singh, R. K., Kumar, S. and Khilari, K. 2014. Effect of different organic amendments on the radial growth of Rhizoctonia solani causing black scurf of potato. Trends in Biosciences, 23 (7): 38743876

Read, P.J. and Hide, G.A. 1988. Effects of inoculum source and on black dot disease of potatoes (Collectotrichum coccodes (Wallr.) Hughes) and its development during storage. Potato Res., 31: 493-500.

Roberts, P. 1999. Rhizoctonia-forming fungi: a taxonomic guide. Royal Botanical Gardens, Kew. pp. 239.

Scholte, K. 1989. Effects of soil-borne Rhizoctonia solani Kühn on yield and quality of ten potato cultivars. Potato Research, 32: 367-376.

Scholte, K. 1992. Effect of crop rotation on the incidence of soil-borne fungal diseases of potato. Netherlands Journal of Plant Pathology, 98 (2): 93-101.

Shatla, M. and Sinclair, J.B. 1963. Tolerance to pentachloronitrobenzene among cotton isolates of Rhizoctonia solani. Phytopathology, 53: 1407-1411.

Singh, B. P., Arora, R.K. and Khurana, S.M.P. 2002. Soil and tuber borne diseases of potato. Central Potato Research Institute, Shimla, India. Technical Bulletin, 41: 74.

Singh, R, Khurana, S.M. P., Singh, B.P. and Narayana, B. M. 2005. Integrated management schedule for control of black scurf disease of potato caused by Rhizoctonia solani. Potato Journal, 32 (34): 181-182.
Slack, S.A. 1993. Seed certification and seed improvement programs. In: Rowe RC. (ed) Potato Health Management. St Paul, MN, APS Press, pp. 61-65.

Stack, R.W., Gudmestad, N. and Salas, B. 1999. Effect of inoculum source and anastomosis group on Rhizoctonia solani black scurf, stem rot and yield. Abstracts of the 14th Triennial Conference of the European Association for Potato Research, Sorrento, pp. 517-518.

Stevens Johnk, J., Jones, R.K., Shew, H.D. and Carling, D.E. 1993. Characterization of populations of Rhizoctonia solani AG-3 from potato and tobacco. Phytopathology, 83: 854-858.

Sturz, A.V., Johnston, H.W. and MacWilliams, C.K. 1995. Weed hosts of Rhizoctonia solani in Prince Edward Island. Canadian Journal of Plant Pathology, 17: 346-352.

Sumner, D.R. 1987. Efficacy of pencycuron against isolates representing different anastomosis groups of Rhizoctonia solani and Rhizoctonia-like binucleate fungi. Plant Disease, 71: 515-518.

Thind, T.S., Mohan, C. and Kaur, S. 2002. Promising activity of pencycuron, a phenylurea-based fungicide, for effective management of black scurf of potato. Indian Phytopathology, 55: 39-44

Tsror (Lahkim), L., Erlich, O. and Aharon, M. 1999. A survey of bacterial and fungal seedborne diseases in imported and domestic potato seed tubers. Phytoparasitica, 27: 215-226.

Tsror, L. 2010. Biology, epidemiology and management of Rhizoctonia solani on potato. Journal of Phytopathology 158: 649-658.

Tuitert, G., Szczech, M. and Bollen, G.J. 1998. Suppression of Rhizoctonia solani in potting mixtures amended with compost made from organic household waste. Phytopathology 88:764-773.

Van Bruggen, A.H.C. and Arneson, P.A. 1984. Resistance in Rhizoctonia solani to tolclofos-methyl. Netherlands Journal of Plant Pathology, 90: 95-101.

Vilgalys, R. and Gonzalez, D. 1990. Ribosomal DNA restriction fragment length polymorphism in Rhizoctonia solani. 
Phytopathology, 80: 151-158.

Virgen-Calleros, G., Olalde-Portugal, V. and Carling, D.E. 2000. Anastomosis groups of Rhizoctonia solani of potato in central Mexico and potential for biological and chemical control. American Journal of Potato Research, 77: 219-224.

Wicks, T.J., Morgan, B. and Hall, B. 1995. Chemical and biological control of Rhizoctonia solani on potato seed tubers. Australian Journal of Experimental Agriculture, 35: 661-664.

Windels, C.E. and Nabben, D.J. 1989. Characterisation and Pathogenicity of Anastomosis Groups of Rhizoctonia solani Isolated from Beta vulgaris. Phytopathology, 79: 83-88.
Woodhall, J.W. and Lees, A.K. 2004. First report of Rhizoctonia solani anastomosis group 5 (AG5) on couch grass in Britain. Plant Pathology, 53: 538.

Woodhall, J.W., Lees, A.K., Edwards, S.G. and Jenkinson, P. 2007. Characterization of Rhizoctonia solani from potato in Great Britain. Plant Pathology, 56: 286-95.

Woodhall, J.W., Lees, A.K., Edwards, S.G. and Jenkinson, P. 2008. Infection of potato by Rhizoctonia solani: effect of anastomosis group. Plant Pathology, 57: 897-905.

Woodhall, J.W., Wharton, P.S. and Peters, J.C. 2012. First Report of Rhizoctonia solani AG4 HG-II infecting Potato Stems in Idaho. Plant Disease, 96: 1701.

\section{How to cite this article:}

Manoj Kumar, Jaywant Kumar Singh, Sanjeev Kumar and Anil Kumar. 2017. A Comprehensive Overview on Black Scurf of Potato. Int.J.Curr.Microbiol.App.Sci. 6(10): 49814994. doi: https://doi.org/10.20546/ijcmas.2017.610.472 